\section{Celebrating science}

\author{
Scientists feel passion, but they need \\ to convey it in their writing, too.
}

\section{John Carmody}

$\mathrm{n}$ n 1963, Sir Peter Medawar published a provocative essay, "Is the scientific paper a fraud?". With characteristic vigour, he asserted that the typical research paper misrepresents the reality of scientific work, in being written as if the venture unfolded in an unchecked and logical way. His argument has resonated with me for years, so I was delighted to discover that Robert Simmons feels the same way ("Sense and sensibility", Nature 411, 243; 2001). In life, as in real laboratories and fieldwork, nothing proceeds with such smooth progress.

Perhaps more importantly, the "fraudulence" is not simply that the process is idealized; the passion is invariably drained too. This is the result of both the scientific culture and the reviewing process: important though both are, they etiolate the paper as an account of what the scientists have achieved. If (like art) science is concerned with understanding the world and our place in it, then it must be a passionate activity. Could anything be more important?

How much of that is apparent in scientific publications? If they have been stripped bare, do they falsify the nature of science? Contrast the cool brevity of Watson and Crick's 1953 account of the structure of DNA with the significance and impact of their paper about the molecule of the twentieth century.

The philosopher A. N. Whitehead thought that language is incomplete and fragmentary; is the problem of science that it must be made complete and concrete? In another essay, "Lucky Jim" (1968), Medawar asserted: "The history of science bores most scientists stiff." Possibly so, but the quiddity of what they do and how they account for that to themselves and their colleagues should be of deep concern. It is reassuring that such scientists as Lewis Thomas, Jared Diamond and Primo Levi (not to mention Medawar himself) have - when roaming beyond the fetters of the scientific paper - transcended that dichotomy.

Clinical scientists have a protean challenge. Their patients, rightly, want them to be highly competent but empathic communicators as well; their colleagues expect them to be simultaneously objective and involved. When they write, it is almost invariably as the dispassionate observer and detailed analyst, yet they can write with emotional honesty.

One, from an earlier era, was Herbert "Paddy" Moran. In his younger days he was a great captain of the Australian Rugby XV; after postgraduate surgical studies, he worked with cancer patients, notably as a pioneer radiotherapist in Sydney. His professional publications are thoughtful but detached, and typical of the period. His three books of memoirs are quite different, especially the third, In My Fashion (1946), in which he described his reaction to the irony of his own diagnosis of melanoma and chronicled his decline towards death. It is intense writing.

"I observed that a pigmented mole which I had had upon the skin of my abdomen was breaking down ... I had no doubt, then, about the breaking down of this skin over a mole ... it is the fatal characteristic of this cancer that, almost at the moment when it appears locally to be breaking down, it has already scattered its evil seed at a distance." Soon after the pathologists confirmed the diagnosis he wrote: "There was nothing to do but to carry on" - he was a medical officer with the Australian Army in Britain — "The immediate effect on myself was a degree of shock from which I reached at once into bravado ... but very clearly I perceived that all my world had changed, whether I liked it or not ... I shall be often unhappy. I shall have pain, and pain, like many men, I never liked to bear ... I have my secret horror of being, before the end, weakened in body and in morale broken, that I shall whimper and complain."

In May 1945 he wrote: "The war ended in Europe yesterday. The crab was turning last night, dragging its tentacles. I awoke and was depressed. The nights are hardest to bear. I note in myself a tendency to slacken off all mental and physical activities. I must not so early throw in the sponge. I must summon up my will-power." A few days later: "The crab has been gnawing again. His nocturnal habits are disreputable ... The process is going to be more rapid than I had expected. Or is it that I am thinking too much on my little complaint? It is terribly hard not

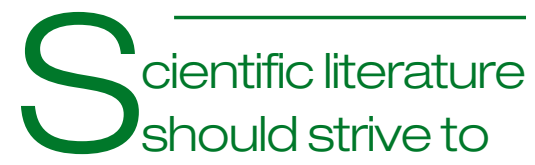
achieve a sense that it is a chapter in an activity that has changed the world.

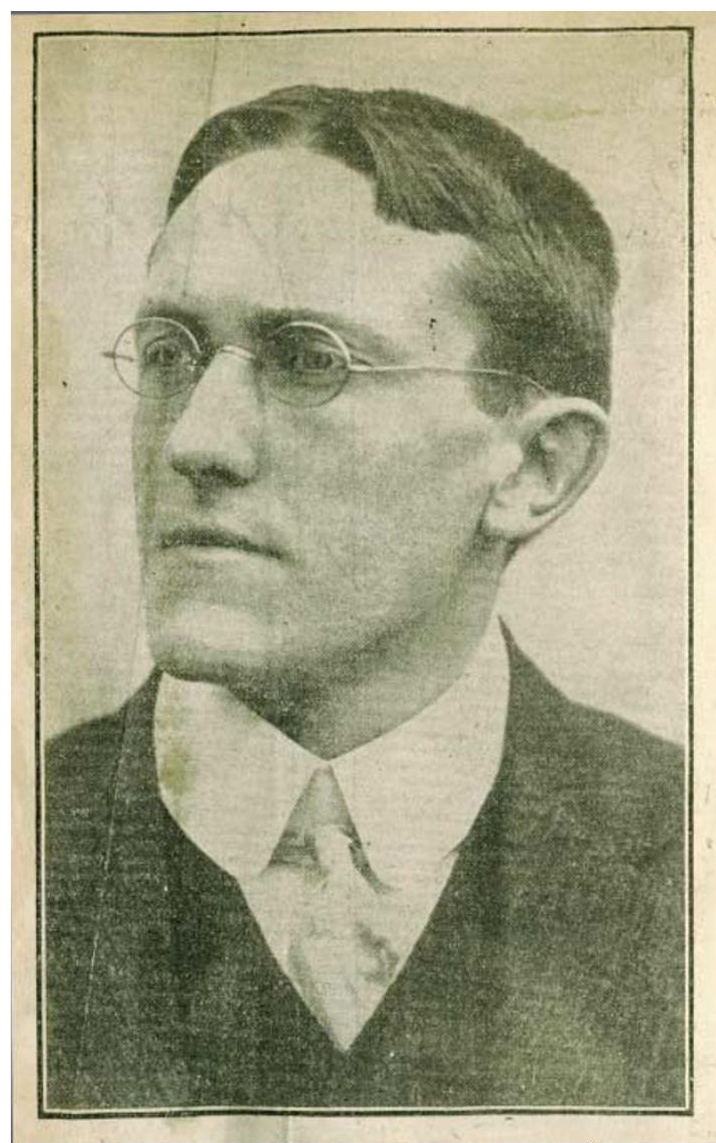

Herbert Moran's professional publications are detached, but his memoirs are quite different.

to think of it. Everything leads back to it."

Having decided to persist with the book, he reflected: "It does not matter if it never comes to birth in publication. It has saved me from a greater degree of unhappiness. After all, this death is a routine affair." By June it was: "My power of concentration is lessening. My interests are shrivelling. The will is like a tyre worn down to the tread. There is no excuse for this letting myself go." His sardonic humour did not desert him: speculating on the likely organ collapse, he wrote: "It is now ten to one on attrition through failure of the liver function. If only I had the energy to write a thriller: Death Comes to the Evil Liver."

Of course, scientific literature cannot be like Moran's eschatological prose. What it ought to strive to achieve - apart from the greatest lucidity - is a sense that it is a chapter in an activity that has changed the world and our insight into our relationship with it; a sense that the authors have been participants in an enormously important and successful human activity one that they should be proud to celebrate. That would make the writing and the reading as thrilling as good science can reallybe.

John Carmody is at the School of Physiology and Pharmacology, University of New South Wales, New South Wales 2052, Australia. 